\title{
Environmental Disclosure in Industrial Companies in Aqaba
}

\author{
Mousa Mohammad Abdallah Saleh \\ E-mail: mousamah@maktoob.com
}

Muneer Mohamad Falah Jaradat
E-mail: Mune_2000@yahoo.com

Mohammad Faroq Huseen Jebreel

E-mail: Yazora2006@yahoo.com

Received: March 6, 2012

Accepted: May 2, 2012 Published: July 1, 2012

doi:10.5296/jmr.v4i3.1481

URL: http://dx.doi.org/10.5296/jmr.v4i3.1481

\begin{abstract}
This study aims to identify the effect of the disclosure on the company's environmental performance. It found that there is a relation between environmental disclosure and both of the company's ability to obtain, and the competitiveness of companies in the industrial companies in Aqaba. But the environmental performance does not lead the companies to get support and incentives from the government, and does not affect in determining the profit rate on loans. Also be found that there is no relation between environmental disclosure and the value of profits for the company in the industrial companies in Aqaba.

It recommends the banks to consider environmental performance in determining the profit rate on loans, and industrial companies to guide environmental performance to lead the companies to get support and incentives from the government.
\end{abstract}

Keywords: Industrial companies, Aqaba, Environmental disclosure, Profits, Credit. 


\section{Introduction}

In the last period of the previous century and in the beginning of the recent, there was a great development in the manufacturing technology. There was also an increased competition among companies. This force companies to keep up with this technology to achieve cash savings. As a result, those companies achieve the desired profits at the expenses of its environmental responsibilities. This development was a reason for the occurrence of environment-interested groups, these groups contributed in increasing awareness among society members, and legislating environmental laws to limit pollution, and preserve environment.

This remarked the development of manufacturing technology, forcing financial accounting as an informational system to measure the financial effects. On the other hand, it was necessary for the financial accounting system, in responding to the social pressures, to measure the effects of these companies on the environmental disclosure. That is, the environmental disclosure is not limited to the financial information, but it includes disclosing other environmental qualitative and quantitative information.

Radi, Sami (1999, page 93) consider that many related parties like, investors, creditors, and workers are in need of information; to help them to have a clear image about the industrial companies performance. This information could be obtained from traditional financial reports. However, the lack of the appropriate information for decision makers leads for the need of other types of information like the social one, which reflects the responsibility of the companies towards the environment. Investors and societies are both in needs for those types of information that affects decision-making process.

This study comes to examine this topic in al- Aqaba city which is located in Jordan. In Aqaba, there are increasing investments especially the foreign ones. It is known that Aqaba is characterized by three features: first, it is the only marine gate in Jordan. Second, it is featured by customs exemptions duties on imports. Third, it is an attractive city for foreign tourists and locals, which considers an important highlight for the environmental disclosure and its effect in improving investment.

\section{Methodology of the Study}

The study based on a descriptive analytical method, where primary data collected from the study society and were analyzed statistically to get the results of the study. The questionnaire was a tool to collect primary data that designed to measure the affect of (AIS), in addition to interview with related authorities.

\section{The Study's Problem}

The industrial companies operating in Aqaba such like other companies may disclose information about its environmental performance. Investors and donors can get this information to use it in their decisions; hence, there are the following questions:

- Is there a statistical relationship between the environmental disclosure and the company's ability to obtain credit in Aqaba's industrial companies? 
- Is there a statistical relationship between the environmental disclosure and the company's competitive ability in Aqaba's industrial companies?

- Is there a statistical relationship between the environmental disclosure and the company's profits value in Aqaba's industrial companies?

\section{The Study's Objectives}

This study aims to identify the effects of the environmental disclosure on the company's performance to obtain loans in Aqaba's industrial companies, the company's competitive ability, and the effect of disclosure in knowing the profits value in these companies.

\section{The Study's Importance}

This study is considered one of the rare studies in terms of the topic, the sample, and the importance of the industrial sector in Aqaba, which has a clear economic importance. However, we need to show the importance of the different parts of environmental disclosure in the financial reports; which has advantages on the society and the financial reports users.

That is Aqaba is characterized by three features: first, it is the only marine gate in Jordan. Second, it is featured by customs exemptions duties on imports. Third, it is an attractive city for foreign tourists and locals, which makes it an important highlight in the subject of environmental disclosure and its effect in improving investment.

\section{The Study's Hypotheses}

The following hypotheses were formed in attempt to answer the raised study's questions:

There is a statistical relationship between the environmental disclosure and the company's ability to obtain credit in Aqaba's industrial companies.

There is a statistical relationship between the environmental disclosure and the company's competitive ability in Aqaba's industrial companies.

There is a statistical relationship between the environmental disclosure and the company's competitive ability profits value in Aqaba's industrial companies.

\section{Society and Sample of Study}

The society of study contains the industrial companies in Aqaba. The samples are 19 companies which represent $26 \%$ from the society.

\section{Statistical Techniques That Used and Testing Hypotheses}

The study calculated the following statistical measures: the mean, $\mathrm{t}$ - test, the Cronbach alpha test, standard deviation, news of variance of the differences, and Tukey test.

As for the answers of questions were to accept the hypotheses, the mean must be greater than 3 , and T-value must be greater than table value, or that the level of significance must be less than 0.05 . 


\section{- 9. Previous Studies}

- $\quad$ Duaa's study (2011)

- This study aims to clarify the effects of disclosing environmental costs in the financial lists of Aqaba's industrial companies, and to clarify its effect on the decisions of accounting information users. The researcher adopted the survey style by using a questionnaire that is distributed to the related groups. The study's main finding was: the environmental disclosure in the financial lists of Aqaba's industrial companies affects the decisions of accounting information users in those industrial companies, and affects the qualitative characteristics of accounting information quality.

- Khaled hussainey \& Aly salam’s Study, (2010)

- This study aims to clarify the effects of the accounting disclosure on the investor's decisions in London stock exchange. In addition to the importance of environmental disclosure on investment decision-making, the study found that there is an important effect of the environmental disclosure on the investor's decisions. The environmental disclosure corrects the investor's decisions and put it on the right direction. It also affects the investor's future performance.

- Al-Taher's Study (2009)

- This study aims to recognize the effect of the environmental costs in evaluating the performance of the Sudanese industrial companies. It aimed to shed the light on the importance of paying attention to the environmental costs in the petroleum sector, which upgrades the companies' performance, and their roles in protecting the environment. It is also aimed to know the effect of the environmental costs in making administrative and financial decisions. The study most important finding was: the high value of the environmental costs affects the awareness toward using techniques to combat the environmental damage, to improve their performance, and to measure and report the environmental costs in some companies. This leads to the rationalizing of the environmental performance.

- The study's most important recommendation was to give an importance to the finding of environmental systems in the industrial companies, to pay an attention to the evaluation of improving the company's performance, and also to increase the environmental awareness among the public and the users of the financial lists.

- Mohammad Mohsen's Study (2008)

- This study aims to form an indicator of the optional environmental disclosure, with applying an empirical study on the registered companies in the Egyptian stock market. These companies belong to an environmental sensitivity sectors.

- On one hand, it was found that there is a difference in practicing the optional environmental disclosure policy among companies. On the other hand, there was other companies work in a standard way (i.e. to work according to one standard and one-way) in 
case of disclosing environmental information. However, regarding the disclosure's quality, it was low in the whole sample of companies. The study recommended the encouraging of companies that discloses the optional environmental information, especially the ones that pay higher costs towards its social, environmental responsibilities. This encouragement was formed by providing these companies a distinctive tax treatment. The study also focused on the importance of applying the environmental disclosure indicator by the stock exchange on the list of environmental sensitivity companies.

- $\quad$ Cormier, D. \& Magnan, M’s Study,( 2007)

- This study aims to clarify the extent of the investors' using of environmental reports, in order to get better profit assessments, and to reduce the perceived expectations. It also examines the relation between the company's environmental reputation and the expectations of contribution to prices and profits. The study found that the high points in the environmental reputation field are associated with stock prices which predict the future returns. This means that the environmental reputation of the company can provide investors with information to enable them to predict future returns.

- $\quad$ Alqtati's study, (2007)

- This study aims to view the nature of the environmental costs and the benefits of the disclosure based on accounting documents. The main hypotheses of the study, which related to the existence of benefits for the accounting information users from disclosing environmental costs, had been examined.

- The study concluded that it is very important to achieve the environmental costs disclosure requirements, according to the importance of the resulting benefits of the shareholding industrial companies, which was listed in the Palestinian capital market.

- The study recommended the Palestinian capital market to give an importance to the companies' environmental disclosure by adopting international accounting standards; in order to determine the costs and its effect on the financial data. In addition, it was recommended to create a method to present the financial lists in a detailed way about the social and environmental performance and its effect on the financial data.

- $\quad$ Sayed Ahmed's study, (2007)

- This study dealt with the accounting and taxation treatment of the environmental costs problems. It showed the awareness of the polluting industries for the environmental considerations, and the disclosure of the environmental performance. It reviewed the roles of the disclosure (voluntary or obligatory) in guiding projects towards the environmental commitment. It also assured the importance of disclosing and recognizing the expected environmental obligations, and using taxes and incentives to combat pollution and achieve the environmental commitment.

- The study concluded the following results:- First, there are some difficulties in measuring the environmental costs such as determining the elements of the environmental costs, 
separating the environmental costs from the economic ones, and linking the costs and benefits. Second, the environmental disclosure is a main component of the over all disclosure, and meets the financial lists users' needs; such as; access information that enables them to assess the environmental performance.

- Cormier study (2004)

- This study aims to find a model that forms the relation between the beneficiaries and the administrations. The administrations know the impact of each party, and their effects on the decision of disclosing environmental information in the annual reports. The sample model was examined on a group of environment officials of international companies in America and Europe. The study concluded that the sample environment officials were aware of the differences of beneficiary's interests, and they had the abilities to assess the interest of each part. In addition, there was a strong relation between the administration's recognition of party's interests and its respond to their expectations in the real disclosure of the environmental information in the financial reports.

- $\quad$ Deegan's Study (2002)

- This study aims to determine the level of environmental disclosure on the Australian major companies' annual reports from the early eighties to late nineties of the last century. It also examined, whether the environmental disclosure was meeting the community's expectations.

- The study relied on the press to measure the society's trends. It followed the content analysis method to measure the interests of press and the environmental disclosure in the annual reports.

- The study concluded that there was an increase in the level of the disclosed environmental information in the annual reports, especially the positive ones. In addition, the environmental issues that got the attention of the news had a larger interest of disclosure in the annual reports.

- Joshi's and others Study, (2002)

- This study showed that each one dollar increase in the environmental costs is associated with an increase in the total costs. The cost ranges from $\$ 10-\$ 11$ and $\$ 9-\$ 10$ are included under the non-environmental accounts. The study confirmed that the increase in the unapparent costs is reflected on the costs systems, and leaded to an inappropriate decision to manage the unapparent costs. In addition, this leaded to an inaccurate cost deviations, and products pricing, or inappropriate products combination selection. It also leaded to wrong decisions regarding closing a factory, or a product line, or other investment decisions.

- O’ Donovan's Study, (2002)

- This study aims to improve the application of legalization theory. It also gets the benefit from the relation between the following three elements: First, the event or the environmental 
technology which may be a legal threat for the institution. Second, the choices between the legalization theory and the disclosure type in the annual reports. Third, the goal of choosing such a method may be the information, the maintenance, or the reform of the company's legal situation. The findings showed that the event or the environmental technology had an important effect in disclosure decisions. That is why companies disclose only the high important and the medium important environmental events, but low important environmental events didn't affect the choice of the legalization method, or the volume of disclosure in annual reports.

- $\quad$ Solomon and Lewis Study, (2002)

- This study aims to recognize the reasons of the environmental disclosure on the British companies, and the exposure of different risks, even though the environmental disclosure is optional. In addition, the reason of the companies' failure in the appropriate disclosure of the environmental information, that comes as a response to the importance of the environmental conservation. According to the authors and users of environmental disclosure, the study found that there are motives for the commitment of laws and regulations, there are changes in the society's culture, and in meeting the demands of the environmental information. The study also found that the increase in the environmental disclosure in Britain don't amount to the expected level. This type of disclosure suffers from inadequacy especially in the small companies.

\section{The Situation of This Study from Previous Ones}

This study differs from other studies in the following points: First, the study sample, according to the researcher knowledge, is the first that examines the industrial companies in Aqaba. Second, it examines the impact of environmental disclosure from three dimensions: the credit ability, the competitiveness, and the profits value.

\section{Description of Personal and Job Factors of Respondents}

Table (1) shows a description of the personal and job factors of the sample of hotel's employees, as follows:

* Specialization: $56.48 \%$ of the sample specialized in accounting, $13.89 \%$ specialized in finance, $10.19 \%$ specialized in Business administration, $6.48 \%$ specialized in management information systems (MIS), and $4.63 \%$ of the sample specialized in others.

* Qualifications: It is shown that $45.37 \%$ of the study sample held bachelor degrees, $39.81 \%$ of the sample are diploma holders, $7.41 \%$ of the sample held masters, $4.63 \%$ of the sample graduated from high schools, and $2.78 \%$ held P.H.D degree.

* Years of experience: The study showed that $58.33 \%$ of the samples have experience between 6- 10 years, $27.78 \%$ have experience between 1 - 5 years, $10.19 \%$ of the samples have experience between 11 - 15 years, and 3.70\% of the samples have experience more than 15 years. 
* Job Level: The table showed that $47.22 \%$ of the samples are section chief, $25.00 \%$ of the samples are officers, $18.52 \%$ are deputy of manager, and $9.26 \%$ are managers.

Table1. Frequencies and percentages for the personal variables of respondents

\begin{tabular}{|c|c|c|c|}
\hline \multicolumn{2}{|l|}{ Factor } & Freq & $\%$ \\
\hline \multirow{5}{*}{ Specialization } & Accounting & 61 & 56.48 \\
\hline & Finance & 15 & 13.89 \\
\hline & Business administration & 11 & 10.19 \\
\hline & Management Information Systems(MIS) & 7 & 6.48 \\
\hline & Other & 14 & 12.96 \\
\hline \multirow{5}{*}{ Qualifications } & High school & 5 & 4.63 \\
\hline & Diploma & 43 & 39.81 \\
\hline & Bachelor & 49 & 45.37 \\
\hline & Masters & 8 & 7.41 \\
\hline & P.H.D & 3 & 2.78 \\
\hline \multirow{4}{*}{ Years of experience } & $1-5$ & 30 & 27.78 \\
\hline & $6-10$ & 63 & 58.33 \\
\hline & $11-15$ & 11 & 10.19 \\
\hline & More than 15 & 4 & 3.70 \\
\hline \multirow{4}{*}{ Job Level } & Manager & 10 & 9.26 \\
\hline & Deputy Manager & 20 & 18.52 \\
\hline & Section Chief & 51 & 47.22 \\
\hline & Officer & 27 & 25.00 \\
\hline
\end{tabular}

\section{Stability of the Tool}

Stability of the tool was tested by Chronbach Alpha Coefficient test. Table (2) shows the following:

Alpha value for the items of the company's ability to obtain credit dimension was 0.75

Alpha value for the items of competitiveness dimension was 0.81

Alpha value for the items of the value of profit dimension was 0.72

Alpha value for the items was 0.85 .

All these values were $>0.60$ which means a stability of the tools (scatter 19). 


\section{Macrothink}

Table 2. Alpha Chronbach values

\begin{tabular}{|l|l|}
\hline Dimension & Alpha \\
\hline The company's ability to obtain credit & 0.75 \\
\hline competitiveness & 0.81 \\
\hline value of profit & 0.72 \\
\hline All items together & 0.85 \\
\hline
\end{tabular}

\section{Hypotheses}

\subsection{First hypothesis}

There is a statistically significant relation between environmental disclosure and the company's ability to obtain credit in the industrial companies in Aqaba.

Table 3 shows that with the exception of item 5, all items obtained arithmetic means $>3.00$ and significance levels $<0.05$, which means that all these are statistically existed. Item (1) which measures how much the environmental disclosure is considered is the main criterion for banks to give credit, ranked the first with a mean of 4.56. Item (4), which measures how much the disclosure of environmental performance affects in the determination of the required guarantees for giving a credit, was in the second rank with a mean of 4.22 . The Item (3) which measures how much the disclosure of environmental performance does not affects in determining the required time for loans paying, was ranked last of the statistically acceptable items with a mean of 3.31. For Item 5 an arithmetic mean was $<3.00$ which means that the environmental performance does not affect in determining the profit rate on loans.

\subsubsection{Test of First Hypothesis}

The table shows that all grouped items have a mean of 3.77, and $0.00 \mathrm{p}$-values, which means that this hypothesis is accepted, and that means there is a statistically significant relation between environmental disclosure and the company's ability to obtain credit in the industrial companies in Aqaba. 


\section{Ml Macrothink}

Table 3. Arithmetic mean, standard deviations, t- value, and p-value of the company's ability to obtain credit:

\begin{tabular}{|c|c|c|c|c|c|}
\hline $\begin{array}{r}\text { Item } \\
\text { No }\end{array}$ & Item details & Mean & $\begin{array}{l}\text { Std. } \\
\text { deviation }\end{array}$ & t-value & P-Value \\
\hline 1 & $\begin{array}{l}\text { The environmental disclosure is considered } \\
\text { the main criterion for banks to give credit. }\end{array}$ & 4.56 & 0.93 & 17.37 & 0.00 \\
\hline 2 & $\begin{array}{l}\text { The disclosure of environmental performance } \\
\text { affects in determining the extension of bank } \\
\text { credit. }\end{array}$ & 3.94 & 1.04 & 9.31 & 0.00 \\
\hline 3 & $\begin{array}{l}\text { The disclosure of environmental performance } \\
\text { affects in determining the required time for } \\
\text { loans paying. }\end{array}$ & 3.31 & 1.43 & 2.29 & 0.02 \\
\hline 4 & $\begin{array}{l}\text { The disclosure of environmental performance } \\
\text { affects in the determination of the } \\
\text { required guarantees for giving a credit. }\end{array}$ & 4.22 & 0.88 & 14.45 & 0.00 \\
\hline \multirow[t]{2}{*}{5} & $\begin{array}{l}\text { The disclosure of environmental performance } \\
\text { affects in determining the profit rate on loans. }\end{array}$ & 2.81 & 1.28 & $1.51-$ & 0.14 \\
\hline & All grouped items & 3.77 & 0.67 & 11.98 & 0.00 \\
\hline
\end{tabular}

\subsection{Second Hypothesis}

There is a statistically significant relation between environmental disclosure and the competitiveness of companies in the industrial companies in Aqaba.

Table 4 shows that with the exception of item 7, all items obtained arithmetic means $>3.00$ and significance levels $<0.05$, which means that all these are statistically existed. Item (10) which measure how much the disclosure of environmental performance improves the company's economic performance level, ranked the first with a mean of 4.51. Item (9) which measure how much the disclosure of environmental performance maximizes the company's profitability in the long term, were in the second rank with a mean of 4.21. Item (12) which measure how much the disclosure of environmental performance increases company's products marketing ability, ranked last of the statistically acceptable items with a mean of 3.97. For Item 7 , the arithmetic mean was $<3.00$ which means that the disclosure of environmental performance does not lead the companies to get supports and incentives from the government.

\subsection{Test of Second Hypothesis}

The table shows that all grouped items have a mean of 3.96, and $0.00 \mathrm{p}$-values, which means this hypothesis is accepted, and this means there is a statistically significant relation between environmental disclosure and the competitiveness of companies in the industrial companies in Aqaba. 


\section{Macrothink}

Journal of Management Research

ISSN 1941-899X

2012, Vol. 4, No. 3

Table 4. Arithmetic mean, standard deviations, t-value, and p-value of the competitiveness between companies:

\begin{tabular}{|l|l|l|l|l|l|}
\hline $\begin{array}{l}\text { Item } \\
\text { No }\end{array}$ & $\begin{array}{l}\text { Item details } \\
6\end{array}$ & $\begin{array}{l}\text { The disclosure of environmental performance provides } \\
\text { different sources of funding for the company. }\end{array}$ & $\begin{array}{l}\text { Std. } \\
\text { deviation }\end{array}$ & P-Value \\
\hline 7 & $\begin{array}{l}\text { The disclosure of environmental performance leads the } \\
\text { company to get support and incentives from the government. }\end{array}$ & 2.79 & 1.70 & -1.30 & 0.20 \\
\hline 8 & $\begin{array}{l}\text { The disclosure of environmental performance decreases the } \\
\text { production and marketing costs in the long term. }\end{array}$ & 3.97 & 0.86 & 11.77 & 0.00 \\
\hline 9 & $\begin{array}{l}\text { The disclosure of environmental performance maximizes the } \\
\text { company's profitability in the long term. }\end{array}$ & 4.21 & 1.34 & 9.41 & 0.00 \\
\hline 10 & $\begin{array}{l}\text { The disclosure of environmental performance improves the } \\
\text { company's economic performance level. }\end{array}$ & 4.51 & 0.69 & 22.72 & 0.00 \\
\hline 11 & $\begin{array}{l}\text { The disclosure of environmental performance increases the } \\
\text { company's shares in the capital markets. }\end{array}$ & 4.10 & 0.80 & 14.38 & 0.00 \\
\hline 12 & $\begin{array}{l}\text { The disclosure of environmental performance increases } \\
\text { company's products marketing ability. }\end{array}$ & 3.97 & 1.11 & 9.07 & 0.00 \\
\hline
\end{tabular}

\subsection{Third Hypothesis}

There is statistically significant relation between environmental disclosure and the value of profits for the company in the industrial companies in Aqaba.

Table 6 shows that, all items obtained arithmetic means $<3.00$, which means that all these are not statistically existed.

\subsubsection{Test of Third Hypothesis}

The table shows that all grouped items has a mean of 2.47 ,, which means that this hypothesis is rejected, and this means statistically there is no significant relation between environmental disclosure and the value of profits for the company in the industrial companies in Aqaba? 


\section{Macrothink}

Journal of Management Research

ISSN 1941-899X

2012, Vol. 4, No. 3

Table 5. Arithmetic mean, standard deviations, t-value, and p-value of the value of profits:

\begin{tabular}{|c|c|c|c|c|c|}
\hline $\begin{array}{r}\text { Item } \\
\text { No }\end{array}$ & Item details & Mean & Std. deviation & t-value & P-Value \\
\hline 13 & $\begin{array}{l}\text { The expenses of preventing environmental } \\
\text { damage caused by the company affect the profits } \\
\text { value. }\end{array}$ & 2.23 & 1.04 & -4.83 & 0.00 \\
\hline 14 & $\begin{array}{l}\text { The expenses of environmental damage remedy } \\
\text { affect the profits value. }\end{array}$ & 2.70 & 1.15 & -1.73 & 0.09 \\
\hline 15 & $\begin{array}{l}\text { The expenses of the remedy of the company's } \\
\text { hazardous waste that can't be reused and } \\
\text { recycled affect the profits value. }\end{array}$ & 2.42 & 1.01 & -3.79 & 0.00 \\
\hline 16 & $\begin{array}{l}\text { The expenses of the remedy of the company's } \\
\text { hazardous waste that can be reused and } \\
\text { recycled affect the profits value. }\end{array}$ & 2.33 & 1.19 & -3.72 & 0.00 \\
\hline 17 & $\begin{array}{l}\text { The expenses of employees' insurance affect the } \\
\text { profits value. }\end{array}$ & 2.60 & 1.14 & -2.28 & 0.03 \\
\hline 18 & $\begin{array}{l}\text { The expenses of training employees who } \\
\text { are involved in keeping and transferring the } \\
\text { company's hazardous materials affect the profits } \\
\text { value. }\end{array}$ & 2.20 & 0.66 & -8.12 & 0.00 \\
\hline 19 & $\begin{array}{l}\text { The expenses of medical examination and } \\
\text { treatment for employees who suffer from } \\
\text { occupational diseases affect the profits value. }\end{array}$ & 2.65 & 1.21 & -1.89 & 0.07 \\
\hline 20 & $\begin{array}{l}\text { The expenses of the imposed fines on the } \\
\text { company's as a reason for not adhering to } \\
\text { standards and environmental laws affect the } \\
\text { profits value. }\end{array}$ & 2.60 & 1.05 & -2.47 & 0.02 \\
\hline 21 & $\begin{array}{l}\text { The expenses of the emergency plan to deal with } \\
\text { any unexpected accident during the production, } \\
\text { storage, or transferring of the hazardous } \\
\text { materials affect the profits value. }\end{array}$ & 2.44 & 1.14 & -3.21 & 0.00 \\
\hline 22 & $\begin{array}{l}\text { The expenses that are related to the environmental } \\
\text { performance disclosure methods affect the profits } \\
\text { value. }\end{array}$ & 2.49 & 0.96 & -3.49 & 0.00 \\
\hline & All grouped items & 2.47 & 0.74 & -4.72 & 0.00 \\
\hline
\end{tabular}




\section{Conclusion}

1- There is statistically significant relation between environmental disclosure and the ability of industrial companies to obtain credits from banks in Aqaba. The environmental disclosure considered the main criterion for banks to give credits, in which, this disclosure of environmental performance effects in determining the amount of bank credits, the required time for paying the loans, and in achieving the required guarantees for getting such a credit. It was also determined that the environmental disclosure does not have an effect on figuring out the profit rate of the loans.

2- There is statistically significant relation between environmental disclosure and the competitiveness of industrial companies in Aqaba. It was determined that the disclosure of environmental performance can provide different sources of funding for industrial companies, decrease the production and marketing costs in the long term, maximize the companies profitability in the long term, improves the companies economically, increases the companies shares in the capital markets, and finally increase company's abilities in marketing their products. It was also determined that the environmental disclosure does not help those companies to get supports and incentives from the government.

3- There is no statistically significant relation between environmental disclosure and the value of profits for the industrial companies in Aqaba.

\section{Recommendations}

1- The study recommends that the industrial companies in Aqaba must continually provide environmental disclosure.

2- Banks should consider the disclosure of environmental performance in determining the profits rate on loans.

3- Industrial companies in Aqaba should guide environmental performance to help in getting support and incentives from the government.

4- When industrial companies consider the possibility of applying environmental disclosure, they should know that there is no negative impact on the value of profits.

\section{References}

Abuser, A. I. (2007). Environmental accounting - Intellectual frame the application elements. Petra University.

Al-jarrah, B. A., \& Idris.M. Kh. (2007). Dimensions measured by the market rates and ratios of operating cash flow in public shareholding Jordanian Industrial companies. Jordan Journal of Business, 3(1), 83-72.

Al-mabrook, N. A. (2009). Review of the impact of environmental factors on the financial lists, University of Qatar. Alqtati, M. J. (2007). The benefits of environmental costs disclosure applied study on the industrial shareholding companies listed on the Palestinian Capital Market, Faculty of Commerce - the Islamic University of Gaza. 


\section{Macrothink}

Journal of Management Research

ISSN 1941-899X

2012, Vol. 4, No. 3

Bamzahm, S. F. (2008). The accounting measurement of the costs of environmental pollution damage to workers in the oil refining sector, An Empirical Study in the Aden Refinery Company, unpublished Ph.D. thesis, Faculty of Economics, University of Damascus, p. 92 Cormier, D. \& Gordan. M. (2004).Corporate Environment Disclosures: Contrasting Management's Perceptions with Reality. Journal of Accountancy, 169.

Darwish, N. M. (2005). The impact of accounting disclosure on the environmental performance of the Jordanian industrial companies to rationalize decisions and the quality of financial reporting - a oral entrance, Faculty of Economics and Administrative Sciences, Zaytoonah University.

Deegan's, C. (2002). Introduction: The Legitimizing Effect of Social and Environment Disclosures a Theoretical Foundation. Accounting, Auditing, and Accountability Journal, 15, 282-311. http://dx.doi.org/10.1108/09513570210435852

Deved, A. (2002). Association of Chartered Certified Accountants. Accounting Report, 7.

Gadin E. (2000). Environmental Disclosure Clarendon press, Oxford.2000.

George O. Gamble and et. Environmental Disclosures in Annual Reports and 10 ks: An Examination, Accounting Horizons, p.37

Hayali, W. N. (2009). Accounting disclosure in light of the expansion of the modern accounting curriculum to include social accounting, Arab Academy in Denmark///Baghdad.

Ibabtin, Kh. A. (2007). Environmental labeling and the competitiveness of key economic sectors, King Saud University.

Kieso, D., \& Weygand. J., \& Warfield. T. (2007). Intermediate accounting, (12th Ed.) New Jersey: Wiley, p173.

Laika, R. K. (2007). Measurement and accounting disclosure in the financial lists of banks and their role in the rationalization of the investment decision, Teshrine University, Syria.

Percerou, R. (2003). Enterprise, question et compétitivité, Paris: ed. Economic, pp (53-58). Peter, l, \& Roger k. Environmental cost accounting and auditing. Managerial Auditing journal, 424-431.

Said, J. I. (2007). Academy, environment now newspaper, Egypt. Shhadh, A. (2010). The accounting measurement of the environmental performance costs of the Syrian company and its influence in their competitiveness in the field of Quality, Faculty of Economics/University of Aleppo. Volume 26 - Issue for the first. Damascus University Journal of Economics and legal.

Solomon, A., \& Lewis, L. (2002). Incentives and Disincentives for corporate Environmental Disclosure. Business strategy and the environment, 11, 154 - 169. http://dx.doi.org/10.1002/bse.328 


\section{Macrothink}

Journal of Management Research ISSN 1941-899X 2012, Vol. 4, No. 3

Syed, A. A. (2007). Tax accounting treatment of environmental costs for projects, "Empirical Study", Faculty of Commerce, Helwan University, letter to a Ph.D. in Accounting unpublished.

Tahir, A. A. (2010). the effect of the environmental costs in evaluating the performance of Sudanese industrial companies. Applicable Analysis to the oil sector, Faculty of Economics and Administrative Sciences / Red Sea University, unpublished Master.

Wild, J. (2003). Subramanian, K.R.; Halsey, Robert. Financial statement analysis, New York - Hill Companies, p384. 